\title{
Correlation between Knowledge and Husband's Attitude on Vasectomy Contraception in the Work Area of Pekauman Health Center, Banjarmasin
}

\author{
Nurul Hidayah ${ }^{1 *}$, Desilestia Dwi Salmarini², \\ ${ }^{1}$ Midwifery Diploma Department, Sari Mulia University, Indonesia \\ ${ }^{2}$ Midwifery Diploma Department, Sari Mulia University, Indonesia \\ *re.firya.hidayah@gmail.com
}

\begin{abstract}
Most people lack knowledge about vasectomy. Some people assume the most responsibility for family planning issues is women and the limited acceptance and accessibility of family planning services and reproductive health. The purpose of this study was to determine the relationship of knowledge with the husband's attitude about vasectomy contraception in the work area of Pekauman Health Center Banjarmasin. This research is an analytic survey with a cross-sectional approach. The sampling technique uses random sampling. The sample in this study was 63 respondents using the Spearman Rank correlation test. The results of the study note that the husband has middle knowledge is $54,8 \%$.and the husband has a negative attitude $75,8 \%$. Spearman Rank correlation test results obtained a correlation between knowledge and the attitude of the husband about vasectomy contraception in the work area of Banjarmasin Puskesmas with $\mathrm{p}$-value $=0.045$. Suggestions in this study are for vasectomy contraception counseling activities to be applied routinely and continuously.
\end{abstract}

Keywords: Knowledge, Attitude, and Vasectomy

\section{Introduction}

The Family Planning Program (KB) is one of the government's efforts to control the population. the family planning program is still dominated by women. The low participation of men in family planning programs, especially vasectomy, is due to many factors, including the limited choice of contraceptive methods for men, the lack of information provided by health workers related to contraceptive methods for men, social stigma in society related to men with vasectomy [1].

One of the operational activities of family planning services is by providing contraception services and family planning assistance. The contraceptive methods available in family planning programs in Indonesia include the simple contraceptive method and the long-term contraceptive method (MKJP). Long-term contraception method (MKJP) in women is in the form of contraception 
in the womb (IUD), subcutaneous contraception (AKBK) and female operative method (MOW), whereas in men there is only one variant, namely the male operative method (MOP). Male Operative Method (MOP) or vasectomy, which is binding and cutting the vas deferens channel so that sperm fluid is not ejaculated [2].

Based on the Indonesian Health Demographic Survey (IDHS) the number of participants MOP is still very alarming compared to the number of other KB participants. The low use of vasectomy as a male contraceptive is due to a lack of knowledge and awareness on the part of men or husbands in addition to the limited types of contraception for men [2].

The participation of married men in family planning in Indonesia is still low at $5.1 \%$. This figure is very low compared to other countries such as Bangladesh 19.1\%, Pakistan 10.9\% and Nepal $18 \%$ [3].

Forms of male participation in family planning can be done directly and indirectly. Direct male participation (as a family planning participant) is a man using one of the methods or methods of preventing pregnancy, such as condoms, vasectomy (male contraception), as well as natural birth control involving men (interrupted copulation method and periodic abstinence methods). Male participation indirectly is a man supporting his wife in family planning, as a motivator who can provide motivation to become a family planning participant, and plan the number of children together with his wife. Correct knowledge of contraception in men is a basic prerequisite for effective use. Desmalita (2008) and Budisantoso (2008) research shows that there is a meaningful relationship between knowledge about family planning and male participation in family planning programs [3].

In addition to knowledge, attitudes towards family planning are needed in men's participation in KB. According to New Com, attitude is readiness or willingness to act, and is not implementing certain motives. Attitude is not yet an action or activity, but is a predisposition to an action or behavior [4]

Based on data obtained from the Banjarmasin City BKKBN office, the number of fertile age couples in the working area of the Banjarmasin Pekauman Health Center in 2016 was 11,105 fertile age couples and in 2017 as many as 11,367 seen an increase in the number of fertile age couples. But seen from active family planning participants there was a decrease, namely in 2016 there were 75,042 participants while in 2017 active family planning participants numbered 66,779 people and in 2018 an increase of 96,197 people. There were no family planning participants who used MOP / Vasectomy in the working area of the Banjarmasin sensitive health center.

Based on a survey conducted with 10 married men, 7 men said they did not know about vasectomy contraception in terms of understanding, vasectomy requirements, advantages and disadvantages and side effects. Only 3 men said that they knew about vasectomy contraception in terms of the benefits and disadvantages, but they assumed that the most responsible for family planning problems were women, not men. In addition, there was a perception that after vasectomy there would be a decrease in libido making husbands reluctant to become vasectomy participants. Therefore the authors feel attracted by the phenomenon of the lack of participation of men who want 
to use family planning, especially vasectomy. so the authors decided to take the title "The Relationship of Knowledge With Husband's Attitude About Vasectomy Contraception in the Work Area of the Banjarmasin Sensitive Health Center".

\section{Material and Methods}

his research uses analytic survey research with cross sectional approach. The population used in this study was the husband of fertile age couples in the working area of RT 29 sensitive community health centers as many as 163 people. The number of samples was 62 people. The sampling technique is random sampling

The independent variable (independent) is knowledge while the dependent variable is the husband's attitude towards vasectomy contraception taken at one time using an instrument in the form of a questionnaire.

After the data is obtained from the samples that have been studied, then the data processing in this research is by editing, coding, tabulating, and presenting data. Univariate data collection is by collecting data about family planning acceptors, especially users of vasectomy contraception and filling out a questionnaire, after the respondent has completed filling in, the questionnaire is collected immediately. after the data is collected, it is tabulated and presented. Univariate analysis was carried out for each variable of the study results [5]. Bivariate analysis used by using the Spearman Rank correlation test [6].

\section{Results}

From the results of data analysis, it can be presented the results of research on the Relationship of Knowledge with Husband's Attitudes About Vasectomy Contraception in Pekauman Health Center.

\subsection{Univariate Analysis}

\subsubsection{Distribution of husband's knowledge About Vasectomy Contraception in the Banjarmasin Pekauman Health Center Work Area below:}

Table 1. Frequency distribution of husband's knowledge of vasectomy contraception 


\begin{tabular}{llll}
\hline No & Knowledge & Frequency & Percentage \\
\hline 1 & Good & 9 & 14.5 \\
2 & Middle & 34 & 54.8 \\
3 & Less & 19 & 30.6 \\
\hline & $\Sigma$ & 62 & 100
\end{tabular}

Sumber Data 2018

From the above data it can be seen that the majority of respondents have sufficient knowledge of 34 people (54.8\%) while the least respondents have good knowledge of 9 people (24.5\%).

\subsubsection{Distribution of husband midwife attitudes About Vasectomy Contraception in Banjarmasindi Pekauman Community Health Center below:}

Table 2. Frequency distribution of husband's attitude About Vasectomy Contraception in the Work Area of Pekauman Health Center Banjarmasin.

\begin{tabular}{llll}
\hline No & Attitude & Frequency & Percentage \\
\hline 1 & Positive & 15 & 24.2 \\
2 & Negative & 47 & 75.8 \\
\hline & $\Sigma$ & 62 & 100 \\
\hline
\end{tabular}

Data Source 2018

From the above data it can be seen that the majority of respondents have a negative attitude of 47 people $(75.8 \%)$ while the respondents who have the least attitude are a negative attitude of 15 people $(24.2 \%)$.

\subsection{Analysis of Bivariate}

In this study, bivariate analysis is used to look for or see the relationship of knowledge with the husband's attitude about vasectomy contraception in the work area of Banjarmasin health center.

Table 3. Relationship between Knowledge and Attitudes About Husband 


\begin{tabular}{|c|c|c|c|c|c|c|}
\hline \multirow{3}{*}{ Knowledge } & \multicolumn{4}{|c|}{ Attitude } & & \multirow[b]{2}{*}{$\Sigma$} \\
\hline & \multicolumn{2}{|c|}{ Positive } & \multicolumn{2}{|c|}{ Negative } & & \\
\hline & $\mathrm{n}$ & $\%$ & $\mathrm{n}$ & $\%$ & $\mathrm{n}$ & $\%$ \\
\hline \multirow[t]{2}{*}{ Good } & \multirow[t]{2}{*}{4} & & \multirow[t]{2}{*}{5} & & 9 & \multirow{2}{*}{14,5} \\
\hline & & 6,5 & & 8,1 & & \\
\hline \multirow{2}{*}{$\begin{array}{l}\text { Pretty } \\
\text { Good }\end{array}$} & \multirow[b]{2}{*}{9} & & \multirow[b]{2}{*}{25} & & 3 & \multirow[b]{2}{*}{54,8} \\
\hline & & 14,5 & & 40,3 & 4 & \\
\hline \multirow[t]{3}{*}{ Less Good } & \multirow{3}{*}{2} & & \multirow{3}{*}{17} & & 1 & \\
\hline & & & & & 9 & \multirow[b]{2}{*}{30,7} \\
\hline & & 3,2 & & 27,4 & & \\
\hline \multirow[t]{2}{*}{$\bar{\Sigma}$} & \multirow[b]{2}{*}{15} & & \multirow[b]{2}{*}{47} & & \multicolumn{2}{|l|}{6} \\
\hline & & $24 ?$ & & $7=0$ & 2 & \\
\hline
\end{tabular}

Seen from table 4.7 above, it can be seen that respondents have the most negative attitudes of 47 respondents $(75.8 \%)$ with sufficient knowledge of 25 respondents $(40.3 \%)$. Statistical test results with the Spearman rank formula obtained a value of 0.045 meaning $p$ value $<\alpha$ means that there is a relationship between knowledge of the husband's attitude about vasectomy contraception in the work area of Pekauman Health Center Banjarmasin.

\section{Discussion}

\subsection{Knowledge}

Knowledge is the result of human sensing or the result of knowing someone about the object through their senses (eyes, nose and so on) [7]. Judging from the knowledge of respondents about vasectomy contraception in the working area of Banjarmasin's Pekauman Health Center, it can be seen that the majority of respondents have sufficient knowledge of $54.8 \%$. From the questionnaire can be seen about number 13 on the item "Binding and cutting sperm canal has many wrong side effects one of which makes men unable to get an erection "at least answer incorrectly.

The above statement is supported that knowledge alone has not been as mobilizing as attitudes, knowledge of knowing a new object becomes an attitude if knowledge of knowing a new object becomes an attitude if that knowledge is accompanied by readiness and awareness to act in accordance with knowledge of the object. Thus it can be concluded that a person's behavior can be based on knowledge and can also not be based on knowledge [7] . 


\subsection{Attitude}

According to Louis Thurstone in defining attitude as a form of evaluation or reaction to feelings. A person's attitude towards an object is a feeling of supporting or impartial (favorable) or a feeling of not supporting or not taking sides (unfavorable). From the results of the study 62 respondents who had a negative attitude there were $75.8 \%$ about vasectomy, this is due to several things one of them is the knowledge of respondents about vasectomy is still low so that no positive nature is formed on him. This shows that an attitude might be realized in an action. This is in line with Green in Notoatmodjo who argues that the predisposing or driving factor in the occurrence of a behavior, one of which is the influence of individual attitudes towards the behavior. However, this weak correlation shows that behavior is not only influenced by the level of knowledge and attitude. Behavior can be influenced by other factors, namely the tendency to act that starts from the respondent himself who is highly motivated and realizes that vasectomy is important to do [8].

\subsection{The relationship of knowledge to the husband's attitude towards vasectomy}

Most respondents have negative attitudes of 47 respondents $(75.8 \%)$ with sufficient knowledge of 25 respondents $(40.3 \%)$. Statistical test results with the Spearman rank formula obtained a value of 0.045 meaning $\mathrm{p}$ value $<\alpha$ means that there is a relationship between knowledge of the husband's attitude about vasectomy contraception in the work area of Pekauman Health Center Banjarmasin.

This is in line with Nasution's research with the title Factors Affecting the attitude of Male KB Accepters in the Work Area of Ambacang Puskesmas Padang City in 2012 with the chi square test results obtained p-value 0.025 meaning that there is a relationship between knowledge and attitude of male KB acceptors [9].

Broadly speaking, the factors that influence vasectomy behavior consist of factors outside the individual and factors inside the individual. Factors outside the individual are environmental factors, both family and peer groups (peer groups). While the factors within individuals that are quite prominent are the knowledge and permissiveness of the individual concerned [10].

This is in accordance with the stages of the change of knowledge into behavior according to Fishbein \& Ajzen which suggests that to become a behavior of a knowledge through the stages of perceiving, interpreting, and is there any importance of the input received for the individual finally decides to behave according to the knowledge obtained or not. So if after reaching the last stage and the individual believes that he has an interest in carrying out vasectomy in accordance with the information he obtained from his knowledge, he will perform the vasectomy operation.

In Notoatmodjo's opinion from experience and research it is proven that behavior based on knowledge will be more lasting than behavior that is not based on knowledge. If the acceptance of new behavior or adoption of behavior through a process like this is based on knowledge, awareness, 
and a positive attitude, then the behavior will be long-lasting. Conversely, if the behavior is not based on knowledge and awareness, it will not last long [11]. 


\section{References}

[1] Indrayani, Teknologi Kontrasepsi. Edisi kedua. Medika Fakultas Kedokteran UGM, Yogyakarta, 2014.

[2] Devi, Skripsi Hubungan Tingkat Pendidikan Dan Pengetahuan Dengan Sikap Istri Dari Akseptor Vasektomi Terhadap Pemilihan Kontrasepsi Vasektomi. 2014.

[3] Musafaah,. Faktor Struktural Keikutsertaan Pria Dalam Ber-Keluarga Berencana (Kb) Di Indonesia. Universitas Lambung Mangkurat. Banjarmasin. 2007

[4] Notoatmodjo, promosi kesehatan, jakarta : Rineka Cipta. 2010.

[5] Arikunto. 2010. Prosedur Penelitian Suatu Pendekatan Praktik. PT Rineka Cipta. Jakarta

[6] Hidayat, Metode Penelitian Kebidanan dan Teknik Analisis Data.Jakarta : Salemba Medika, 2010

[7] Notoadmodjo, Metode Penelitian kesehatan. Jakarta: Rineka Cipta. 2010.

[8] Azwar, Saifuddin. Sikap Manusia Teori dan Pengukurannya. Pustaka Pelajar, Yogyakarta. 2013

[9] Al-Mighwar. 2006. Psikologi Remaja : Petunjuk bagi Guru dan Orangtua. Bandung : Pustaka Setia.

[10] Nasution, Faktor-Faktor Yang Mempengaruhi sikap Akseptor Kb Pria Di Wilayah Kerja Puskesmas Ambacang. 2012

[11] Notoatmodjo, Soekidjo. Promosi Kesehatan dan Prilaku Kesehatan, Jakarta : Rineka Cipta. 2012 